\title{
SEAFOOD TOXINS AND POISONINGS
}

\section{Berna KILINÇ ${ }^{1}$, Aysu BESLER ${ }^{2}$}

(This paper was presented as poster presentation at FABA 2014 (International Symposium on Fisheries and Aquatic Sciences) congress.)

\section{ABSTRACT}

Seafood poisoning is the foodborne illness associated with the consumption of shellfish and fish that contain toxins. Shellfish toxins are produced by certain dinoflagellate species. Bivalve shellfish, especially mussels, clams and oyster can accumulate so many toxins by ingesting with filter-feeding. Shellfish have mechanisms that prevent the hazardous effects of these toxins. Although the toxins do apparently not harm the shellfish and fish, humans eating toxic seafood may become poisoned. These toxins can not be eliminated by cooking procedures. Toxins that cause poisining on fish are produced by spoilage bacteria. The deterioration of fish (tuna, sardine etc.) causes toxins to occur. Seafood poisoning (paralytic shellfish poisoning (PSP), ciguatera poisoning, scombroid poisoning, etc.) is a serious illness and the toxins (saxitoxin, tetrodotoxins, etc.) that are responsible for this illness pose a great risk to seafood safety and public health. Paralytic shellfish poisoning (PSP) and scombroid poisoning are common seafood toxicity problems. The inability of finding an antidote for seafood poisoning makes this foodborne illness even more serious. By waiting shellfish in clean water to obtain the reduction on toxin levels can be the solution for protection from poisoning. In this review, the characteristics of toxins and their effects on human health are discussed.

Keywords: seafood toxins, shellfish, fish, seafood poisonings

\footnotetext{
${ }^{1}$ Ege University Fisheries Faculty, Fish Processing Technology Department, İzmir, Turkey

${ }^{2}$ Muğla Sitkı Koçman University, Faculty of Science, Department of Biology, Muğla, Turkey, abesler@mu.edu.tr
} 


\section{SU ÜRÜNLERİ TOKSINNLERİ VE ZEHIRLENMELERİ}

\section{öz}

Su ürünleri zehirlenmeleri, toksinleri içeren balık ve kabuklu su ürünlerinin tüketimiyle oluşan besin kaynaklı hastalıktır. Kabuklu su ürünleri toksinlerini bazı dinoflagellata türleri üretirler. Çift kabuklular, özellikle midye, istiridye ve deniz tarağ 1 süzerek beslenme yaparak birçok toksini biriktirirler. Kabuklu su ürünleri, bu toksinlerin tehlikeli etkilerini önleyici mekanizmaya sahiptir. Toksinlerin kabuklu su ürünlerinde ve balıklarda zararlı etkilerinin olmamasına rağmen, toksin içeren su ürünlerini yiyen kişiler için zehirli olabilir. Bu toksinler, pişirme işlemleri ile giderilemezler. Balık zehirlenmesine sebep olan toksinler bozulma bakterileri tarafından üretilir. Balık (tuna, sardalya vb.) bozulması toksinlerin ortaya çıkmasına sebep olur. Su ürünleri zehirlenmeleri (paralitik kabuklu su ürünü zehirlenmesi (PSP), ciguatera balık zehirlenmesi, skombroid zehirlenmesi, vb.) ciddi bir hastalıktır ve bu hastalığın sorumlusu olan toksinler (saksitoksin, tetradotoksin, vb.), su ürünleri güvenliği ve halk sağlığı için büyük bir risk yaratır. Paralitik kabuklu su ürünü zehirlenmesi (PSP) ve skombroid zehirlenmesi, en sık görülen su ürünleri zehirlenmeleridir. Su ürünleri zehirlenmesi için bir antidot bulunmaması, bu besin kaynaklı hastalığı daha da ciddi şekle getirir. Kabuklu su ürünleri toksin seviyelerinin azalması için, temiz suda bekletme, zehirlenmeden korunmak için çözüm olabilir. Bu incelemede, toksinlerin karakteristikleri ve insan sağlığına etkileri tartışı1mıştır.

Anahtar kelimeler: Su ürünleri toksinleri, kabuklu su ürünleri, balık, su ürünleri zehirlenmeleri.

\section{INTRODUCTION}

The term toxin refers in a specific way to a toxic substance of biologic origin; that is, a true toxin is a poison produced by a living organism. Classified according to origin, toxins include bacterial toxins, mycotoxins (fungal toxins), phytotoxins (plant toxins), and venoms (toxins from invertebrate or vertebrate animals) (Salzman et al., 2006). Marine biotoxins are algal metabolits that can accumulate in fish or shellfish and render 
these foodstuffs improper for human consumption (Zendong et al.,2014). Marine toxins include phycotoxins; cyanobacterial toxins (including anatoxins; microcystines and nodularins; and saxitoxins, associated with paralytic shellfish poising); a diatom toxin (domoic acid, associated with amnestic shellfish poisoning); dinoflagellate toxins (including berevetoxins associated with neurotoxic shellfish poising, ciguatoxins (Salzman et al., 2006).

Seafood is an extremely diverse food commodity representing most animal phyla, and is produced in a wide spectrum of marine and freshwater environments. Seafood production environments are potential sources of almost every known foodborne hazard including pathogens, parasites, marine toxins and chemical contaminants (DePaola, 2014). The biomass we consume as seafood starts out as unicellular marine plankton, transformed through one or more steps into fish or shellfish. Unfortunately, some species of plankton produce potent natural toxins that accumulate in seafood and can cause dealth or serious illness in human consumers. To manage the problem, we need to understand the nature of the toxins and the organisms that produce them. Such information, together with experience from recent outbreaks, is helping to guide the development of more costeffective approaches for ensuring seafood safety (Hall, 1996). The marine environment may be seriously affected by contamination due to the massive proliferation of toxic phytoplanktonic species for example 'toxic algea' or 'algal blooms', which appear at certain times of the year under the influence of various environmental factors. These phytoplanktonic microorganisms are essential food for filter-feeding bivalve shellfish as well as other types of marine seafood. This phenomenon is commonly known as a 'red tide'(Gago-Martinez and Rodriguez-Vazquez, 2000). Jellyfish blooms occur throughout the world. Human contact with a jellyfish induces a local reaction of the skin, which can be painful and leave scaring. Systemic symptoms are also observed and contact with some species is lethal (Badre, 2014). Marine toxins also have environmental impacts, including significant marine mammal mortalities as well as birth mortality and fish kills. As a consequence of ecological changes from antropogenic activities and climate changes favoring the proliferation of toxic microalgae, the risks from marine toxins have increased in recent years (Tubaro et al., 2012). Toxic cyanobacterial blooms are an emerging issue worldwide, 
particularly in developing countries. because of increasing amounts of nutrient pollutants in surface waters and warmer weather patterns. The increasing number of cyanobacteria-infested surface waters used for drinking, irrigation, and recreation water constitute a potential risk to public health, domestic animals and wildlife. Proliferations of cyanobacteria can produce hepatotoxins, neurotoxins and cytotoxins. Microcystins, anatoxin$\mathrm{a}(\mathrm{s})$ are most commonly associated with fatal poisining of domestic animals and wildlife (Puschner and Roegner, 2012). Important health concerns have recently appeared around shellfish (diarrheic, paralytic, amnesic, neurologic and azaspiracid) and fish (ciguatera and puffer) poisonings produced by different types of phycotoxins (Campas et al.,2007). This review summarizes the marine toxins including origin, their effects on human beings, environment and food industry.

\section{SHELLFISH TOXINS AND POISONING}

Bivalve mollusks filter large volumes of water when grazing on microalgae, and they can concentrate both bacterial pathogens and phycotoxins. These shellfish, especially mussels, scallops, oysters, and clams, are major vectors for toxins that are implicated in several human toxic syndromes. The accumulation of toxins in shellfish and fish has led to serious human toxicosis, as well as animal and bird deaths (James et al., 2008).

\section{DIARRHETIC SHELLFISH POISONING (DSP)}

Marine dinoflagellates of the genus Dinophysis can produce toxins of the okadaic acid (OA) and pectenotoxin (PTX) groups. These lipophilic toxins accumulate in filter-feeding shellfish and cause an illness in consumers called diarrhetic shellfish poisoning (DSP) ( Fux et al., 2011). Diarrhetic shellfish poisoning is a severe gastrointestinal illness caused by the consumption of shellfish contaminated with toxic dinoflagellates such as certain Dinophysis and Prorocentrum species (Bouaicha, et al., 1997). Diarrhetic shellfish poisoning (DSP) is a gastrointestinal illness caused by consumption of shellfish contaminated with DSP toxins such as okadaic acid (OA) and dinophysistoxins (DTX). The occurrences of $\mathrm{OA}$ in bivalves induce not only public health problems but also economic damages to shellfish farming (Sassolas et al., 2013). 
Shellfish consumers are exposed to the risk of diarrhea from, among other contaminants, algae that produce diarrhetic shellfish poisoning (DSP) toxins, such as Dinophysis spp. These illnesses have been effectively prevented since 1984, when a phycotoxin monitoring network was set up along the coasts of France. There is nonetheless concern that residual levels of okadaic acid, a known tumor promoter that is the main toxin present in French coastal waters, might increase the risk of cancer among regular shellfish consumers ( Cordier et al.,2000).

Okadaic acid is a polyether derivative of 38-carbon fatty acid,(Fig.1.) and is implicated as the causative agent of diarrhetic shellfish poisoning. It is a potent tumour promoter that is not an activator of protein kinase $\mathrm{C}$, but is a powerful inhibitor of protein phosphatases-1 and -2A (PP1 and PP2A) in vitro ( Haystead et al., 1989). DSP toxins are tumour promoters that could increase colorectal cancer (CRC) risk (Manerio et al., 2008).

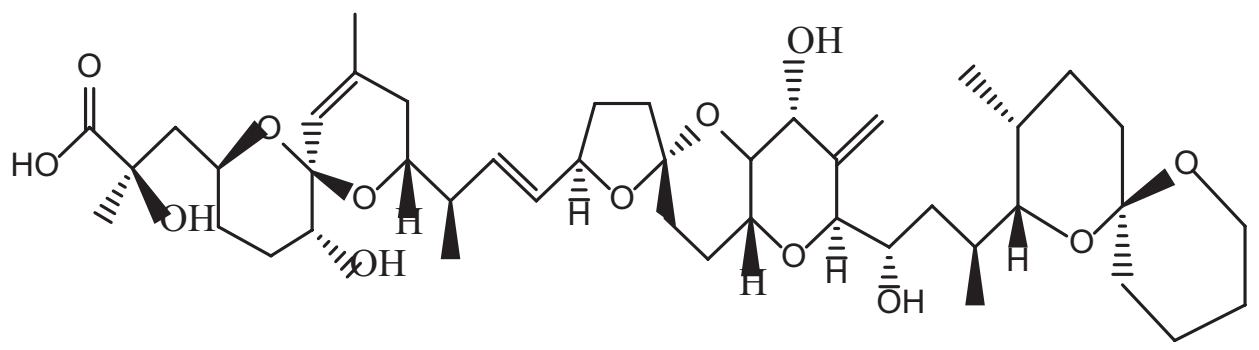

Okadaic acid prorocentrum spp.

(dinoflagellate)

Fig. 1. Marine toxins and their sources (Bhakuni et al.,2005, Kalaitzis et al.,2010,).

\section{PARALYTIC SHELLFISH POISONING (PSP)}

Paralytic shellfish poisoning (PSP) is caused by consumption of saxitoxin contaminated shellfish (Fig. 2.)(Reboreda, et.al.,2010). Saxitoxin is a toxic compound found naturally in dinoflagellates. Its toxicity stems from its ability to bind to voltage-gated sodium channels 
found in membranes of excitable cells such as neurons and muscle cells, blocking synaptic transmission. The toxic effects of saxitoxin primarly effect peripheral nervous system and can alter cardiac chronotrophy. In humans, the estimated lethal dose is $0.3-1 \mathrm{mg}$, while a single contaminated shellfish may contain 50 lethal doses (Gad, 2014).

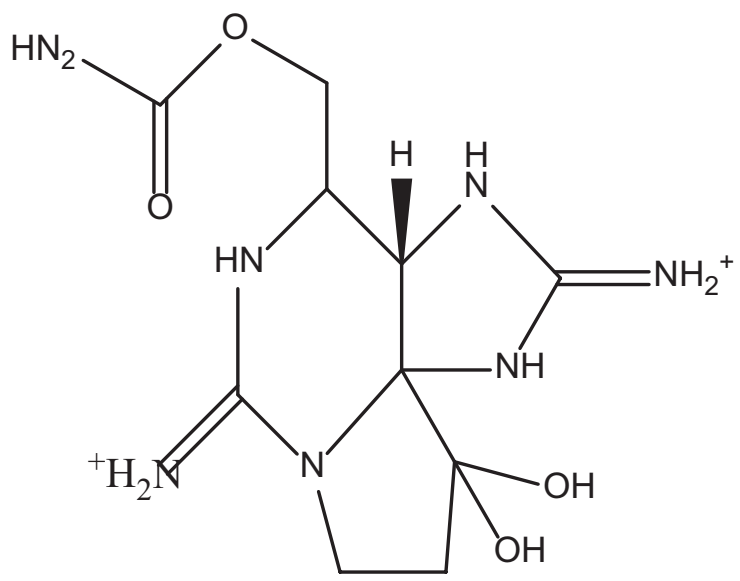

Saxitoxin

Cylindrospermopsis sp.

(cyanobacteria)

Fig 2. Marine toxins and their sources (Bhakuni et al.,2005, Kalaitzis et al.,2010,)

Symptoms include tingling, numbness, headaches, weakness and difficulty breathing. Medical treatment is to provide respiratory support, without which the prognosis can be fatal. To protect human health, seafood harvesting bans are in effect when toxins exceed a safe action level (typically $80 \mu \mathrm{g}$ STX eq $100 \mathrm{~g}^{-1}$ tissue). Though worldwide fatalities have occurred, successful management and monitoring programs have minimized PSP cases and associated deaths. Much is known about the toxin sources, primarily certain dinoflagellate species, and there is extensive information on toxin transfer to traditional vectors-filter-feeding molluscan bivalves. Non-traditional vectors, such as puffer fish and lobster, may also pose a risk (Etheridge et al., 2010). 


\section{AMNESIC SHELLFISH POISONING (ASP)}

Amnesic shellfish poisoning (ASP) is caused by consumption of shellfish that have accumulated domoic acid, a neurotoxin produced by some strains of phytoplankton. The neurotoxic properties of domoic acid result in neuronal degeneration and necrosis in specific regions of the hippocampus. A serious outbreak of ASP occurred in Canada in 1987 and involved 150 reported cases, 19 hospitalisations and 4 deaths after consumption of contaminated mussels. Symptoms ranged from gastrointestinal disturbances, to neurotoxic effects such as hallucinations, memory loss and coma (Jeffery et al.,2004).

Domoic acid is a potent neurotoxin that is naturally produced by several diatom species of the genus Pseudo-nitzschia. The toxin acts as a glutamate agonist and is excitotoxic in the vertebrate central nervous system and other glutamate receptor-rich organs. Human exposure to domoic acid occurs via the consumption of contaminated shellfish that have accumulated the toxin while filter feeding on toxigenic phytoplankton during blooms (Lefebvre et al., 2010)

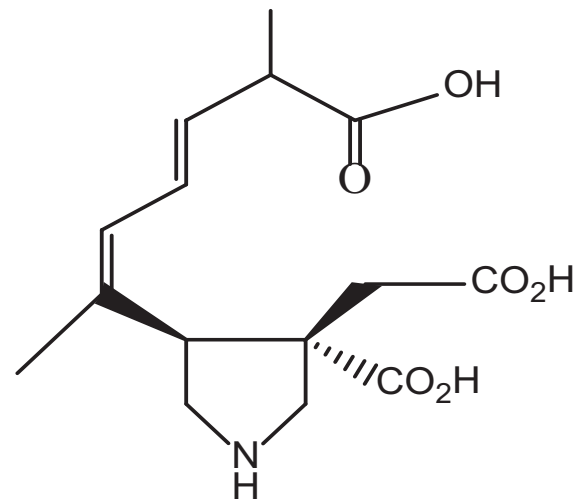

Domoic acid

Pseudonitzshia spp.

(diatom)

Fig. 3. Marine toxins and their sources (Bhakuni et al.,2005, Kalaitzis et al.,2010,) 
Domoic acid has no known function in defence or primary metabolism; a role in excretion of excess photosynthetic energy (Fig.3.) or as a binding ligand for trace metals is suggested. The variability in domoic acid production by different Pseudo-nitzschia spp., or the presence of toxic and non-toxic strains of the same species, cannot be explained. The conclusion is drawn that an increase in toxic blooms of Pseudo-nitzschia spp. might be possible, especially because of the expected increase in nutrient availability from pollution and desert dust. Global warming may have an influence as well by lengthening the growth period for Pseudo-nitzschia, enlarging their global distribution and increasing the dust load through desertification (Mos, 2001).

\section{NEUROTOXIC SHELLFISH POISONING (NSP)}

The toxic dinoflagellate, Karenia brevis, produces a suite of polyether neurotoxins (brevetoxins, $\mathrm{PbTx}$ ) that cause massive fish kills and neurotoxic shellfish poisoning. A unique characteristic of $K$. brevis blooms is the associated airborne (aerosolized) toxin component causing respiratory irritation to humans and other mammals (Pierce et al., 2005)

Brevetoxins are a family of ladder-frame polyether toxins produced by the marine dinoflagellate Karenia brevis(Fig.4.). During blooms of $K$. brevis, inhalation of brevetoxins aerosolized by wind and wave action can lead to asthma-like symptoms in persons at the beach. Consumption of either shellfish or finfish contaminated by $K$. brevis blooms can lead to the development of neurotoxic shellfish poisoning. The toxic effects of brevetoxins are due to binding at a defined site on, and subsequent activation of, voltage-sensitive sodium channels (VSSCs) in cell membranes (Gold et al.,2013). 


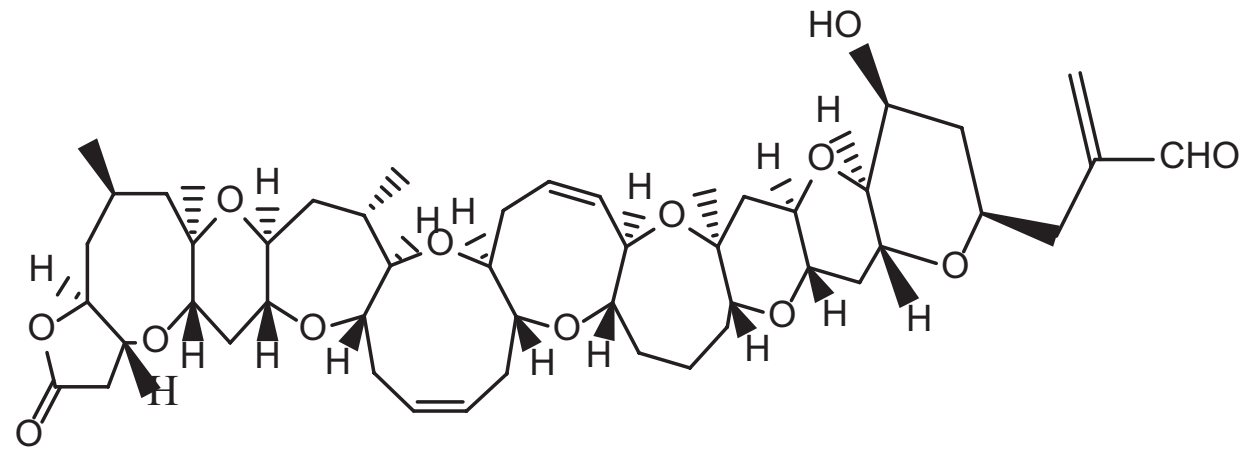

Brevetoxin

Karenia brevis

(dinoflagellate)

Fig 4. Marine toxins and their sources (Bhakuni et al.,2005, Kalaitzis et al.,2010,)

\section{AZASPIRACID SHELLFISH POISONING (AZP)}

A new human toxic syndrome, azaspiracid poisoning (AZP), was identified following illness from the consumption of contaminated mussels (Mytilus edulis) (James et al.,2003).

A new type of food poisoning resulting from ingestion of mussels produced in Ireland occurred in the Netherlands in 1995 and then reoccurred in Ireland in 1997. As the causative agent, azaspiracid, was isolated in pure form and revealed to have a structure entirely unlike other known algal toxins, in vivo studies with mice were carried out to elucidate the pathological injuries caused by the toxin. By per os administration, the toxin caused necrosis in the lamina propria of the small intestine and in lymphoid tissues such as thymus, spleen and the Peyer's patches. Both T and $\mathrm{B}$ lymphocytes were injured. Additionally a fatty change was observed in the liver. These injuries distinctly differed from those caused by the representative diarrhetic shellfish toxin, okadaic acid ( Ito et al., 2000).

Azaspiracids (AZAs) are a group of lipophilic polyether compounds first detected in Ireland which have been implicated in shellfish poisoning 
incidents around Europe (Fig.5.). These toxins regularly effect shellfish mariculture operations including protracted closures of shellfish harvesting areas for human consumption. The armoured dinoflagellate Azadinium spinosum Elbrächter et Tillmann gen. et sp. nov. (Dinophyceae) has been described as the de novo azaspiracid toxin producer; nonetheless the link between this organism and AZA toxin accumulation in shellfish has not yet been established (Salas et al., 2011). Azaspiracid poisoning caused by AZA-contaminated seafood consumption is primarily manifested by diarrhea in humans. To protect human health, AZA-1, AZA-2 and AZA-3 content in seafood has been regulated by food safety authorities in many countries. Recently AZAs have been reported as a low/moderate hERG channel blockers. Furthermore AZA-2 has been related to arrhythmia appearance in rats, suggesting potential heart toxicity (Ferreiro, et al., 2014).

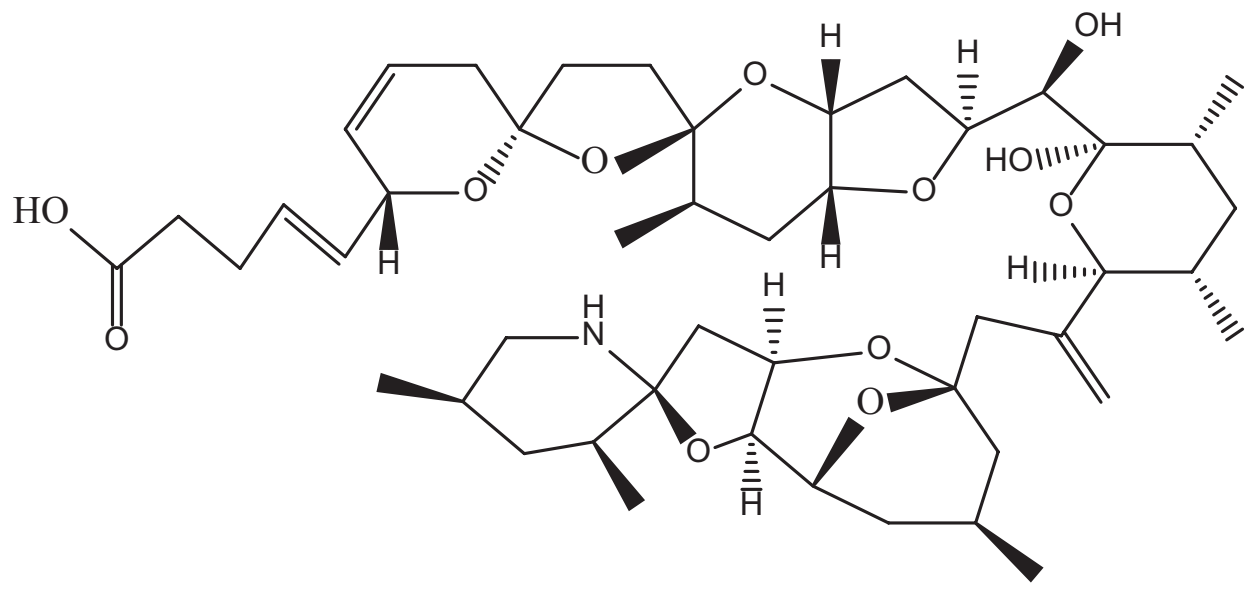

Azaspiracid

Protoperidium sp.

(dinoflagellate)

Fig. 5. Marine toxins and their sources (Bhakuni et al.,2005, Kalaitzis et al.,2010,) 


\section{FISH TOXINS AND POISONING}

\section{CIGUATERA FISH POISONING}

Ciguatera fish poisoning is a seafood-borne illness caused by consumption of fish that have accumulated lipid-soluble ciguatoxins. In the United States, ciguatera is responsible for the highest reported incidence of food-borne illness outbreaks attributed to finfish, and it is reported to hold this distinction globally. Ciguatoxins produce a complex array of gastrointestinal, neurological and cardiological symptoms. Treatment options are very limited and supportive in nature (Dickey et al.,2010).

Ciquatoxin is produced by the dinoflagellate Gambierdiscus toxicus, and related dinoflagellates. These microorganisms live attached to microalgae that are subsequently eaten by fish found in the area where this toxin is largely found in the coral reef waters. This toxin is then stored in the viscera and flesh of the fish where it can remain for years (Eldridge and Holstege, 2005). Ciguatera may result from the eating of fish containing ciguatoxins. Ciguatoxins are heat stable, lipid soluble, colorless, odorless and does not degrade with cooking or freezing. The diagnosis of ciguatera is dependent on the presence of characteristic signs and symptoms and a history of fish consumption. Symptoms are predominantly gastrointestinal with some patients developing neurological symptoms such as parasthesias of the lips and extremities, hot-cold temperature reversal, and painful dysesthesias (Darracq, 2014). The lethal effects of the ciguatoxins in fish may impose an upper limit on the levels of ciguatoxin carried by fish, which could contribute to the low incidence of human fatality associated with ciguatera (Lewis, 1992).

\section{PUFFER FISH POISONING}

Marine puffer fish of family Tetraodontidae accumulate a considerable amount of tetrodotoxin (TTX) mainly in the liver and ovary (Matsumoto et al., 2015). This toxin is also isolated from the skin and viscera of the pufferfish. The toxin is produced by various species of bacteria, and TTX bearing animals absorb and accumulate it through the food chain (Karimi and Lari, 2014). The TTX producing microbes found in four different 
phylum (Proteobacteria, Actinobacteria, Firmicutes and Bacteroidetes), the Proteobacteria are the dominating one. In most of the cases, TTX producing microbes are found in the intestine of the TTX.producing vector indicating the origin of TTX through food chain (Pratheepa and Vasconcelos, 2013): The food chain has been consistently implicated as the principal means of TTX intoxication. The process followed by small carnivores, omnivores or scavengers, and by organisms higher up the food chain would result in in the accumulation of higher concentration of TTX. Pufferfish at the top of the food chain are intoxicated with TTX (Noguchi, et al. 2006).

Tetrodotoxin (TTX) is the toxic component which inhibits the sodium channels selectively and potently, and is used extensively as a laboratory tool for various physiological and pharmacological studies (Narahashi, 2014). This toxin is a nonprotein, water-soluble, heat stable neurotoxin found in fish from the order Tetraodontiformes whose suborders include the Tetrodontoidei (pufferfish and porcupine fish) and Moloidei (sunfish). Tetrodotoxin has also been detected in a variety of animals (newts, salamanders, frogs, the goby, some shellfish, starfish, some species of ribbonworm, the flatworm, crab, horse shoe crab, some species of red calcareous alga and the Australian blue-ringed octopus) (Scharman, 2005). Tetrodotoxin can be lethal to humans being 10000 times more potent than cyanide. Human fatalities have been attributed to the ingestion of this toxin through consumption of pufferfish, a delicacy in Japan and other regions, and other marine species (Campbell and Haughey, 2014).

Tetrodotoxin (TTX) poisoning is characterized by mild gastrointestinal effects and descending paralysis that rapidly progresses to respiratory failure in severe cases, with a high fatality rate. Findings from recent patient studies using novel excitability techniques established unique changes in human nerve and also confirmed that the neurotoxic effects in cases of puffer fish poisoning can be explained by TTX blockade of $\mathrm{Na}$ channels (Kiernan, 2009). Eugenol is a fast and reversible blocker of of tetrodotoxin resistant $\mathrm{Na}$ currents, with affinity 5 times lower than that of lidocaine for the same channel isoforms. Compared to lidocaine, eugenol has a higher relative affinity for the resting state and lower relative affinity for the open /inactive channel state, as unveiled by low dependence on voltage and frequency of the blocking action (Carvalho-de- 
Souza and Cassola,2009). Most TTX poisioning cases are associated with non-professional sport fishermen who are not understand the risk of toxic parts residues of puffer fish prepared without knowledge and appropriate license. The authors suggest that consumer and sport fishermen education are critically important to minimize potential risk of TTX poisoning (Toda et al., 2014).

The biological significance and neurophysiological role of TTX have been elucidated and TTX may act as an important drug like anesthetic in future (Hwang and Noguchi, 2007):

\section{SCOMBROID POISONING}

Scombroid poisoning, also called histamine fish poisoning, is an allergy-like form of food poisoning that continues to be a major problem in seafood safety (Hungerford, 2010).

The highest morbidity world-wide from fish poisoning results from the ingestion of spoiled scombroid fish, such as tuna and mackerel, and its cause is not clear. Histamine could be responsible, because spoiled scombroid fish contain large quantities of histamine (Morrow et al., 1991). Symptoms are produced by histamine release and resemble those encountered with IgE-mediated food allergies. The illness is characterized by flushing, headache, dizziness, burning sensation in the mouth and throat, abdominal cramps, nausea, vomiting, and diarrhea. Urticaria and generalized pruritus are often manifest. In more severe cases bronchospasm and respiratory distress may develop (Sanchez-Guerrero et al., 1997).

Inadequate cooling following harvest promotes bacterial histamine production, and can result in outbreaks of scombroid poisoning. Fish with high levels of free histidine, the enzyme substrate converted to histamine by bacterial histidine decarboxylase, are those most often implicated in scombroid poisoning (Hungerford, 2010). Scombroid poisoning is the most significant cause of illness associated with seafood. Scombrotoxin is of bacterial origin and halophilic Vibrio spp. causing high histamine levels are implicated as the source. Scombroid poisoning is geographically diverse and many species have been implicated, namely: tuna, mahi-mahi, 
bluefish, sardines, mackerel, amberjack and abalone. Temperature abuse has been cited as a major cause of scombroid poisoning ( Lipp et al., 1997).

\section{CONCLUSIONS}

In order to avoid seafood poisoning caused by toxins, shellfish should not be consumed in the periods when algae produce toxins. The most effective control method is to regularly take samples from the regions that shellfish are collected. The control procedures should be planned and toxins should be identified. As the next step, efforts should be made to obtain an antidote against toxins by determining molecule structures of them. Also as a precaution to poisonings, shellfish should be subjected to depuration process after collecting. Waiting shellfish in clean water can be the solution for reducing toxin levels and protection from poisoning. Fish should be transported by cold chain to consumers. The transportation process after catch of fish is important because histamine production tends to increase with temperature rise. The research and controls on seafood toxins and poisonings should be increased and statistical data should be generated.

\section{REFERENCES}

Badre, S.,(2014). Bioactive Toxins from Stinging Jellyfish, Toxicon, Special Issue : Freshwater and Marine Toxins, 91,1, 114-125.

Bhakuni, D.S., Rawat, D.S.,(2005). Bioactive marine natural products, Anamaya Publishers, New Delhi, India.

Bouaicha, N., Hennion, M.C., Sandra, P., (1997). Determination of okadaic acid by micellar electrokinetic chromatography with ultraviolet detection. Toxicon, 35,2, 273-281.

Carvalho-de-Souza, J.L., Cassola, A.C. (2009). Eugenol blocks Tetrodotoxin- Resistant Nav Channels. Biophysical Journal, 96, 3, $251 \mathrm{a}$.

Campas, M.,Prieto-Simon, B., Marty, J.-L.,(2007). Biosensors to detect marine toxins: Assessing seafood safety, Talanta, 72, 884-895.

Campbell, K., Haughey, S. (2014). Natural Toxicants: Tetrodotoxin. Encyclopedia of Food Safety. Vol.2, Hazard and Diseases, 277-282.

Cordier,S., Monfort, C., Miossec, L., Richardson, S., Belin, C.,(2000). 
Ecological analysis of digestive cancer mortality related to contamination by diarrhetic shellfish poisoning toxins along the coasts of France, Environmental Research, 84,2, 145-150.

Darracq, M.A.,(2014). Ciquatoxin. Encyxlopedia of Toxicology (Third Edition), 963-965.

Dickey, R.W., Plakas, S. M.,(2010). Ciguatera: A public health perspective, Toxicon, 56,2, 123-136.

DePaola, A. (2014). Safety of Food and Beverages: Seafood. Encyclopedia of Food Safety, Volume:3, Foods, Materials, Technologies and Risks, 260-267.

Eldridge, D., Holstege, C.P.( 2005). Ciguatoxin, Encyclopedia of Toxicology (Second Edition), 610- 611.

Etheridge, S.M., (2010). Paralytic shellfish poisoning: Seafood safety and human health perspectives, Toxicon, 56, 108-122.

Ferreiro,S.F., Vilarino,N., Louzao, M.C., Nicolaou, K.C., Frederick, M.O., Botana, L.M., (2014). In vitro chronic effects on hERG channel caused by the marine biotoxin azaspiracid-2, Toxicon, 91,1, 69-75.

Fux, E., Smith,J.L., Tong, M., Guzmán, L., Anderson, D.M.,(2011). Toxin profiles of five geographical isolates of Dinophysis spp. from North and South America, Toxicon, 57, 275-287.

Gold, E.P., Jacocks, H.M., Bourdelais, A.J., Baden, D.G., (2013). Brevenal, a brevetoxin antagonist from Karenia brevis, binds to a previously unreported site on mammalian sodium channels, Harmful Algae, 26,12-19.

Ito, E., Satake, M., Ofuji, K., Kurita, N., McMahon, T., James, K., Yasumoto, T., (2000). Multiple organ damage caused by a new toxin azaspiracid, isolated from mussels produced in Ireland, Toxicon, 38, 7, 917-930.

James, K.J., Moroney, C., Roden, C., Satake, M., Yasumoto, T., Lehane, M., Furey, A., (2003). Ubiquitous 'benign' alga emerges as the cause of shellfish contamination responsible for the human toxic syndrome, azaspiracid poisoning, Toxicon, 41,2,145-151.

James, K.J., O’Driscoll, D., Fernandez, J.G., Furey, A., (2008). Phycotoxins, Comrehensive Analytical Chemistry, 429-456.

Jeffery, B., Barlow, T., Moizer, K., Paul,S., Boyle, C.,(2004). Amnesic shellfish poison, Food and Chemical Toxicology, 42,4, 545-557. 
Hall, S. (1996). Seafood toxins: outbreaks, research, and management. Toxicon, 34, 3, 307.

Haystead,T.A., Sim,A.T., Carling D., Honnor, R.C., Tsukitani, Y., Cohen, P., Hardie, D:G., (1989). Effects of the tumour promoter okadaic acid on intracellular protein phosphorylation and metabolism, Nature,337,78-81.

Hungerford,J.M.,(2010). Scombroid poisoning: A review, Toxicon, 56, 231-243.

Hwang, D.F., Noguchi, T. (2007). Tetrodotoxin Poisioning, Advances in Food and Nutrition Research, 52,141- 236.

Gad, S.E. (2014). Saxitoxin.Reference Module in Biomedical Sciences, Encyclopedia of Toxicology (Third edition), 218-220.

Gago- Martinez, A., Rodriguez-Vazquez, J.A.( 2000). Marine Toxins: Chromatography, Reference Module in Chemistry, Molecular Sciences and Chemical Engineering, from Encylopedia of Seperation, Science, 3269- 3277.

Gold, E.P., Jacocks, H.M., Bourdelais, A.J., Baden, D.G., (2013). Brevenal, a brevetoxin antagonist from Karenia brevis, binds to a previously unreported site on mammalian sodium channels, Harmful algae, 26, 12-19.

Kalaitzis, J.A., Chau, R., Kohli, G.S., Murray, S.A., Neilan, B.A., (2010). Biosyntheis of toxic naturally-occurring seafood contaminants, Toxicon, 56, 244-258.

Karimi, G., Lari, P. (2014). Tetrodotoxin. Reference Module in Biomedical Sciences Encyclopedia of Toxicology(Third Edition), 515-518.

Kiernan, M.C. (2009). IN70-FR-01 Marine Toxin Poisining, Journal of Neurological Sciences, 285, 1, 50-51

Lefebvre, K.A., Robertson, A., (2010). Domoic acid and human exposure risks: A review, Toxicon, 56 (2): 218-230.

Lewis, R.J. (1992). Ciguatoxins are potent ichthyotoxins, Toxicon, 30,2, 207-211.

Lipp, E.K., Rose, J.B., (1997). The role of seafood in foodborne diseases in the United States of America, Revue.scientifique et.technique., 16, 2:620-40.

Manerio, E., Rodos,V.L., Costas, E., Hernandez, J.M., (2008). Shellfish consumption: A major risk factor for colorectal cancer, Medical Hypotheses, 70,2,409-412. 
Matsumoto, T., Kiriake, A., Ishizaki, S., Watabe, S., Nagashima, Y. (2015). Biliary excretion of tetrodotoxin in the cultured pufferfish Takifugu rubripes juvenile after intramuscular administration, Toxicon, 93, 98-102.

Morrow, J.D., Margolies, G.R., Rowland, J., Roberts, L.J., (1991). Evidence that histamine is the cause toxin of scombroid-fish poisoning, The new England journal of medicine, 324, 11.

Mos, L., (2001). Domoic acid: a fascinating marine toxin, Environmental toxicology and pharmacology, 9,3, 79-85.

Narahashi, T. (2014). Tetrodotoxin. Encyclopedia of the Neurological Sciences (Second Edition), 420-422.

Noguchi, T., Arakawa, O., Takatani, T. (2006). TTX accumulation in pufferfish. Comparative Biochemistry and Physicology Part D : Genomics and Protelmics, 1,1, 145-152.

Pierce, R.H., Henry, M.S., Blum, P.C., Hamel, S.L., Kirkpatrick, B., Cheng, Y.S., Zhou,Y., Irvin, C.M., Naar, J., Weidner, A., Fleming, L.E., Backer, L.C., Baden, D.G.,( 2005). Brevetoxin composition in water and marine aerosol along a Florida beach: Assessing potential human exposure to marine biotoxins, Harmful algae, 4, 6, 965-972.

Pratheepa, V., Vasconcelos, V. (2013). Microbial diversity associated with tetrodotoxin production in marine organisms. Environmental Toxicology and Pharmacology, 36, 3, 1046-1054.

Puschner, B., Roegner, A.( 2012). Cyanobacterial (blue-green algae) toxins. Chapter 72, Veterinary Toxicology (Second Edition), 953-965.

Reboreda,A., Lago,J., Chapela, M.-J., Vieites, J.M., Botana, L.M., Alfonso, A., Cabado, A.G., (2010). Decrease of marine toxin content in bivalves by industrial processes, Toxicon, 55, 235-243.

Salas, R., Tillmann,U.,John, U., Kilcoyne, J., Burson, A., Cantwell, C., Hess, P., Jauffrais, T., Silke, J.,( 2011). The role of Azadinium spinosum (Dinophyceae) in the production of azaspiracid shellfish poisoning in mussels, Harmful Algae, 10,6,774-783.

Salzman, Matthew, Madsen, J.M., Greenberg, M.I. (2006). Toxins :Bacterial and Marine Toxins, Clinics in Laboratory Medicine, 26, 2, 397-419.

Sanchez-Guerrero, I., Vidal, J.B., Escudero, A.I.,(1997). Scombroid fish poisoning: A potentially life-threatening allergic-like reaction, Journal of Allergy and Clinical Immunology, 100, 3, 433-434. 
Sassolas, A., Hayat A., Catanante, G., Marty, J.( 2013). Detection of marine toxin okadaic acid: Assessing seafood safety. Talanta, 105, 306316.

Scharman, E. J. (2005). Tetrodotoxin. Encyclopedia of Toxicology (Second Edition). 161-162.

Toda, M., Uneyama, C., Kasuga, F. (2014). Trends of tetrodotoxin poisonings caused by puffer fish in Japan. Toxicology Letters, 229, 10, 184.

Tubaro, A., Sosa, S., Hungerfold, J. (2012). Toxicology and diversity of marine toxins- Chapter 69. Veterinary Toxicology, (Second Edition), 896- 934.

Zendong, Z., Brissard, C., Herrenknecht, C., Tixier, C., Abadie, E., Mondeguer, F., Sechet, V., Amzil, Z., Hess, P. (2014). 10 Extended evaluation of mixed -mode and lipophilic sorbents for passive sampling of marine toxins, Toxicon, Special Issue: Freshwater and Marine Toxins, 91, 1, 168-169. 